Tech Otherwise • CSCW '20

\title{
Building a Bigger Tent for \\ Socially Responsible \\ Technology Activism
}

Douglas Schuler

Published on: Oct 15, 2020

DOI: 10.21428/93b2c832.f00db1ea

License: Creative Commons Attribution 4.0 International License(CC-BY 4.0). 


\title{
Building a Bigger Tent for Socially Responsible Technology Activism
}

\author{
By Douglas Schuler \\ Public, Sphere Project \\ douglas@publicsphereproject.org
}

I am not a member of any organized political party. I am a Democrat.

- Will Rogers

In June 2020, a workshop entitled Computing Professionals for Social Responsibility: The Past, Present and Future Values of Participatory Design, was convened virtually at the Participatory Design conference that had been planned to be held in Manizales, Colombia. That workshop was a prelude to this CSCW workshop and could be said to have been using the idea and the institutional realization of Computer Professionals for Social Responsibility to assess / diagnose the current state of social responsibility of computing systems and the computer professionals that envision, design, build, maintain, and modify them with the intent to improve the social responsibility.

The non-profit educational organization, Computer Professionals for Social Responsibility (CPSR), began in the early 1980's through discussions around the use of computers in war, specifically the use of artificial intelligence. The organization evolved over the years through a variety of means into a "big tent" organization that looked at a wide variety of issues and ultimately included the concept of a working group which could help the organization adapt to changes over time. Five CPSR members could identify a topic that they believed needed addressing and a new working group could be created that worked with the CPSR board and other members to conduct research and propose and implement action agendas.

For a variety of issues CPSR ran out of steam - and money. Their last big event was a conference Technology in Wartime in 2007. The board stopped meeting at some point and in 2013 CPSR was officially unincorporated. The remaining funds were dispersed to the Public Sphere Project (PSP) whose mission was (and is) especially related. The understanding was that PSP would attempt to further CPSR's aims, which I am still trying to pursue.

Starting before the advent of CPSR and during and after its demise, the number of organizations and informal groups working to help determine the direction of computing, limiting those uses that were deemed objectionable and promoting those that were seen as desirable, has risen. But the existence of 
other organizations doesn't necessarily mean that the field is saturated. It's also quite possible that things are growing worse in relation to irresponsible computing corporations and systems. With that as background, the PDC workshop posed this question:

"What should a CPSR for the 21st century look like? The CPSR wound down over a decade ago, but today, organizations like it are more needed than ever. What could such an organization achieve? What should it be like? How could it come to be? Many organizations, initiatives, collectives and individuals already speak to these concerns. How can they connect and cooperate more effectively?"

There was definite consensus on the need for dedicated and critical work in this area using perspectives from CPSR, its big tent perspective, for example, and its democratic approach to its own governance. There was also-in my opinion-a majority of people there who were opposed to starting a new organization. I may have been the sole proponent of a new big-tent organization, one that shared aspects of the prior organization but with important distinct differences. I certainly agree that there are different ways to organize ourselves to increase direct and indirect coordination without initiating another formal organization.

\section{Defund Big Tech / Refund Community}

At the same time there was a shared willingness to continue to push in the directions discussed in the workshop. One of example of this is this CSCW workshop. Another one is an ambitious writing project (which is still in-work) that is proposing to "defund big tech" and "refund community." The hope is to build on the current calls for defunding certain sectors including the police, mass incarceration, and the military-industrial complex by calling for significant oversight and regulations accompanied with a transfer of funds of ill-gotten gains from the tech giants to community and civic projects that help build democracy, equity, health, education, and empowerment.

The first section concentrates on the outsized power of Big Tech, including digital intrusions into both public and private lives, and how it came to be that way while the other two sections discuss ways of taming these misuses. The second section provides a series of suggestions to the stakeholders which include:

- Big Tech (and other tech businesses)

- Governments and Policymakers

- Tech professionals/workers, researchers and their organizations

- Civil Society organizations and social movements

- Individuals (consumers, business, investors) 
The third section discusses some history of community and civic tech which was innovative and was often way ahead of the commercial tech side-without, of course, their deep reservoir of funding. It also suggests the immensity of problems, including environmental degradation and climate as well as mass incarceration, institutional racism, fake news, authoritarianism worldwide, and other problems that in the primacy of profit for corporations are not garnering sufficient attention. One important thrust here is that cleaning up the mess that big tech creates is not enough: We are trying to reenergize citizen participation and approaches such as community networking, participatory budgeting, and citizen assemblies are likely to be part of the solution.

\section{Why a Bigger Tent?}

The need for a bigger tent (or tents!) for activism responsible computing is that the tech companies and many authoritarian (and somewhat-less authoritarian) governments are continuing along their harmful trajectories with seemingly minor resistance. In other words, the problems are increasing in spite of considerable resistance. The work we outline in the defund article we are writing suggests the necessity of a better organized resistance. The reality is that we are out- resourced in virtually every arena.

The question then becomes what could we gain by increasing collaboration among groups and across institutional sectors and national borders - and how to we do that. We would have to overcome inertia and lack of resources-including time. Can we identify ways to somewhat cheaply increase our synergy?

Why might additional collaboration - or different approaches to collaboration - benefit the efforts of the whole? Here are some thoughts on that question. The first is that the issues generally (or often) are connected; issues don't really exist in isolation. Without this focus on collaboration valuable connections - between, for example, academia and activists, or across borders-might not happen. The second is that there is a need for loose coordination; efforts sometimes need to be pushing in the same direction at the same time and at the time avoiding to the appropriate degree working at cross purposes. That is, some groups blast Facebook while others use it as their primary organizing platform. Some groups obtain major funding for their mission from tech companies and are probably more likely to omit those companies from their critical eye.

\section{Recommendations}

The defund tech work suggests a number of chores that need to be accomplished. It might also be possible to help develop a bigger tent around the idea of social responsibility in computingresponsible computing? One way to do with this without creating an organizational "leader" or unwanted hierarchy would be to create a shared mission statement or manifesto among various groups, one that also affirmed the commitment to work with other groups. Another might be to initiate 
cross-organizational working groups along the lines of the CPSR working groups, based on the issues, for example, that I heard from the PDC workshop:

\begin{tabular}{|c|c|c|}
\hline $\begin{array}{l}\text { Democratic media - Citizen } \\
\text { assembly }\end{array}$ & Communities & $\begin{array}{l}\text { Climate change and environmental } \\
\text { degradation }\end{array}$ \\
\hline Algorithmic transparency Education & $\begin{array}{l}\text { Rights and Responsibilities Corporate } \\
\text { accountability Inequality }\end{array}$ & Public Policy (not just tech policy) \\
\hline Worker rights & $\begin{array}{l}\text { Deadly Force: War, Terrorism, } \\
\text { Policing, and Crime }\end{array}$ & $\begin{array}{l}\text { Socially responsible institutions - } \\
\text { socially responsible engineering }\end{array}$ \\
\hline $\begin{array}{l}\text { Authoritarianism and Democracy } \\
\text { Privacy }\end{array}$ & Surveillance Capitalism & Voices of the Unheard \\
\hline
\end{tabular}

Perhaps each working group should have a liaisons to the broader group. And maybe there should be a working group itself working towards integration and cross-fertilization. What would increased collaboration look like? It could be imagined in myriad ways, none of which may actually resemble the end result.

I fear that we have little chance of actually making the progress we need to make without at least partially re-thinking the way computer professionals collaborate - with each other, the institutions they work for, and the rest of humankind, worldwide-and take action. 